\title{
Bee conservation policy at the global, regional and national levels*
}

\author{
Andrew BYRNE, Úna FITZPATRICK \\ National Biodiversity Data Centre, Beechfield House, WIT West Campus, Carriganore, Waterford, Ireland
}

Received 13 August 2008 - Revised 10 January 2009 - Accepted 27 January 2009

\begin{abstract}
Bees are important both ecologically and economically for the ecosystem service role they play as pollinators. Documented global decline in bees has sparked the formation of a global policy framework for pollinators, primarily through the International Pollinator Initiative within the Convention of Biological Diversity. There are now regional Pollinator Initiatives, along with regional and national conservation legislation, that can impact on the conservation of bees. The creation of bee Regional Red Lists, under guidance from the International Union for Conservation of Nature, along with conservation priority lists offer another mechanism for streamlining bees into regional, national or subnational conservation policy and practice. These structures, if utilised properly, can form a coordinated and effective policy framework on which conservation actions can be based.
\end{abstract}

conservation / policy / bee / international pollinator initiative / legislation

\section{INTRODUCTION}

Insects are the most important animal pollinator groups, with approximately $70 \%$ of angiosperm plants being insect pollinated (Schoonhoven et al., 1998). Among the pollinating insects, bees are one of the most important and specialised groups (Danforth et al., 2006). There are over 19500 valid species of bee on the planet described thus far (Ascher et al., 2008), though there are likely to be many more species that are to be described (Michener, 2000). Morphologically bees are adapted to collect, manipulate, transport and store pollen very effectively and efficiently (Thorp, 2000; Danforth et al., 2006). Bees species exhibit both generalist and specialist foraging behaviour, thus making them very important economically and ecologically (Waser and Ollerton, 2006). Economically, animal pollination services have been valued at

Corresponding author: A. Byrne, abyrne@biodiversityireland.ie

* Manuscript editor: Robert Paxton
\$65-75 billion globally (Pimentel et al., 1997) and honeybee pollination alone in the United States was evaluated at \$14.6 billion in 2000 (Morse and Calderone, 2000). Bees are often considered keystone species in ecosystems, thus bee loss or decline can result in reduced fruit and seed-set in plants and can lead to disruption of plant-pollinator networks leading to possible extinction cascades (SteffanDewenter and Tscharntke, 1999; Waser and Ollerton, 2006). There has been widespread concern over the status of bees worldwide in recent decades (Allen-Wardell et al., 1998; Kearns et al., 1998) with a number of publications documenting large scale declines (e.g. Corbet et al., 1991; Buchman and Nablan, 1996; Kremen and Ricketts, 2000; Biesmeijer et al., 2006).

There are a number of existing policy platforms that impact on the conservation of the world's bee fauna. These frameworks operate at a number of political and geographical hierarchical levels, from global to regional and national initiatives. All these policies must 
ultimately impact at the national and local level, which is where most actions are brought into practice.

In this paper we review some of the global, regional and national policies and legislation that impact bee conservation. This will enable us to highlight the policies that work well and where further developments could be made. Specifically we aim to describe what we see as the major policy frameworks, and how they interrelate and effect real change on the ground.

\section{THE INTERNATIONAL POLLINATOR INITIATIVE OF THE CBD}

With respect to pollinators, there is an overarching global framework in place that guides initiatives at lower policy levels. This framework has a relatively short history. During the mid 1990's global concern emerged regarding the survival of pollinator diversity from research within academic and other wildlife institutional sources (Watanabe, 1994). From this increased awareness "The Forgotten Pollinators Campaign" was launched in 1995 in the United States. The campaign and an accompanying book, of the same name (Buchmann and Nabhan, 1996), were successful in publicising this concern within North America. The devisors of the campaign called for policy changes to protect habitats for pollinators and suggested subsidising farmers to do so (Ingram et al., 1996). In 1996, the Third Conference to the Parties (COP3) of the Convention on Biological Diversity (CBD) gave pollinators priority for the publication of case studies in its agro-biodiversity programme. The Convention on Biological Diversity legitimised the global concerns through prioritising pollinators in their Conservation and Sustainable use of Agricultural Biological Diversity programme. This led to an international pollinator workshop, with the emphasis on bees, hosted by the Brazilian Government at the University of São Paulo in October 1998 (Dias et al., 1999). A total of 61 scientists from 15 countries and 5 International organisations attended. A result of this workshop, the "The São Paulo Declaration on Pollinators" was produced, and it was in this document that an International Pollinator Initiative (IPI) was proposed (Imperatriz-Fonseca and Dias, 2004; Freitas et al., 2009). The IPI was officially formed in May 2000 at the 5th Conference to the Parties (COP5) of the CBD in Nairobi, Kenya with the endorsement of the São Paulo Declaration. The executive secretary of the CBD invited the Food and Agriculture Agency (FAO) of the United Nations (UN) to facilitate and coordinate the IPI in cooperation with other relevant organisations. The FAO, in collaboration with key experts, developed a Plan of Action (POA) for the IPI. This plan, which built on recommendations from the São Paulo Declaration on Pollinators, was accepted and adopted by member countries at COP6 (April 2002). The IPI's major role and objective is to "promote coordinated and proposed action worldwide" and it is the global policy platform for pollinators, including bees.

\subsection{International Pollinator Initiative-Plan of Action (IPI-POA)}

This IPI-POA is an international agreement that outlines guidance for improving and/or developing policies and practices to enhance pollinator conservation and habitat restoration.

The IPI-POA (http://www.cbd.int/ decisions) was designed to promote a number of aims that would be coordinated at a global level (Williams, 2003). These aims are summarised below (taken from Williams, 2003):

- Monitor pollinator decline, its causes and its impact on pollination services;

- Address the lack of taxonomic information on pollinators;

- Assess the economic value of pollination and the economic impact of decline of pollination services;

- Promote the conservation and the restoration and sustainable use of pollinator diversity in agriculture and related ecosystems.

The plan itself has 4 elements: assessment, adaptive management, capacity building and mainstreaming. These elements each have respective objectives, rationales and time frames 
with expected deliverables (found at: http:// www.cbd.int/agro/pow.shtml). In addition to the IPI-POA, a book, edited by Eardley et al. (2006), was produced. The book reflects the plan's main elements along with case studies, references, recommendations and best practices, and acts as a valuable resource for policy makers and conservationists. Below are summaries of the plan's four elements (adapted from: International Pollinator Initiative Plan of Action, 2002; Williams, 2003; Eardley et al., 2006).

\subsubsection{Assessment of bees and their services}

In the IPI-POA, implementation of practices and policies that allow for assessment of both bee declines and reduced deposition of pollen on stigmas (diminished fruit/seed set in economically and ecologically important plants) is recommended. Measuring trends in diversity and distribution can lead to increased knowledge of the key resource needs of bee pollinators which can feed directly into regional action plans and local habitat management. The action highlights the need for verifiable assessment results and proposes that standardised methods be developed and applied, where possible, globally. An example of a large scale scheme is the ALARM (Assessing LArge scale Risks for biodiversity with tested Methods) project in Europe (Settele et al., 2005). Results of the ALARM assessments will lead to a Risk Assessment Toolkit (RAT) which will be communicated to stakeholders for broader application (Settele et al., 2007).

Bee monitoring protocols need to be developed and refined, and where possible integrated into existing long term studies at national levels to give baseline information. Funding and teaching to increase the taxonomic capacity across regions is essential to allow for strategic and competent bee recording.

The POA proposes that studies between commercial and ecological interest groups be encouraged. Research into the economic value of bees as pollinators should continue, and policies that improve both bee diversity and economic output from agro-ecosystems developed.

\subsubsection{Adaptive management}

The IPI-POA suggests that a strategy of implementing adaptive management techniques be adopted nationally and transnationally with the specific goal of benefitting both crops and wildlife. Adaptive management relates to management of both pollinators and ecosystems; for example, importation of exotic pollinators into a region has been shown to be highly unfavourable to native bee species (Goulson et al., 2002; Goulson, 2003; Stout and Morales, 2009). The POA recommends that within agro-ecosystems native bee pollinators be utilised where possible; they also suggest developing husbandry techniques and methods for increasing native species abundance. Husbandry improves the pollination process and gives higher crop yields, while providing local employment. From a regulatory policy perspective all exotic pollinator importations should be monitored for the potential introduction of invasive species. It is also advised that a risk assessment and cost benefit analysis be carried out before any proposed importation or translocation takes place.

Local site management should promote maximum diversity of both floral and pollinator resources (reviewed in Murray et al., 2009). Intelligent application of knowledge can improve bee diversity by utilising structurally diverse flowering communities with overlapping flowering periods and avoiding concentration on plants of low bee benefit (i.e. low nectar and pollen yields).

Bee population augmentation is suggested as a practice that may increase local bee populations. High quality habitats can act as reservoirs of bee diversity and be used to improve adjacent less diverse areas (e.g. Kremen et al., 2004; Ricketts, 2004; Blanche et al., 2006).

Research into, and proper use of, agrochemicals is essential for maintaining and rehabilitating bee communities. Alternatives to pesticides such as biological control and integrated pest management are encouraged 
for rehabilitation strategies. Non-toxic alternatives should be promoted through educational outreach to specific groups and institutions such as farmers and agricultural colleges.

\subsubsection{Building capacity}

Awareness of bee conservation issues operates at many levels and should be promoted locally to globally. The actions proposed include the widespread dissemination of high quality and easy to understand information to the general public and to special interest groups. The IPI supports policies that promote the collection and dissemination of biodiversity data, such as regional and national biodiversity recording centres. Institutional capacity building includes developing conservation networks, infrastructure (databasing, websites), and making relevant information and literature available to interested parties. An important step in building capacity is the development of targeted educational and outreach material which is disseminated appropriately. The role of the internet as an important tool in aggregating and facilitating information sharing is stressed. Already there are global databases that hold data on bees and make it freely available, for example the Global Bee Checklist (Ascher et al., 2008), held online on the Integrated Taxonomic Information System (ITIS) website. This checklist has been the result of collaborative work between a number of organisations, including ITIS, which have involvement in bee information initiatives (Global Biodiversity Information Facility (GBIF), The Inter-American Biodiversity Information Network (IABIN), The Food and Agricultural Organisation (FAO)) (Remsen and Ruggiero, 2007). Another proposed awareness strategy is the development of 'pollinator friendly' products and branding.

\subsubsection{Getting bees into policy - mainstreaming}

The IPI's role is to promote coordinated action worldwide for the conservation and sustainable use of pollinators, including bees.
This global platform for pollinator conservation and management policy recognises that, on a practical level, conservationists and land managers have few guidelines for bee management plans and no direct policy framework in place to introduce them. Policy makers are more likely to include pollination services within existing sectoral and governmental legislation (discussed below); thus the IPI supports mainstreaming of pollinators into existing policies at global (see Tab. I for potential policy instruments), regional or national levels.

An extremely important element of the initiative is the development of additional research programmes to further understand plant-pollinator systems. This research will increase understanding on the functioning of these systems and allow for specific recommendations that can be incorporated into preexisting schemes. Organisations such as the International Commission on Plant-Bee Relations (ICPBR) will support such initiatives. Ideally bee awareness and management should be brought into rural development plans and land management practices.

Pollinator conservation should be integrated into agroecosystem research and policy. Practices and policies that support the conservation of natural habitat areas, the growing of bee favoured plants and mixed farming initiatives should be supported. National incentives that require uncultivated and unsprayed habitats around cropland provide bees with nest sites and food resources. The IPI also supports national policy that discourages the misuse of agrochemicals, especially those that are of particular threat to pollinator communities.

At the National level a strategy for the integration of pollination and pollinators into National Biodiversity Strategies and Action Plans (NBSAPs) is paramount. Effective strategies to incorporate bees into national plans would emphasise their ecosystem services role and improve the chances of effective enforced conservation strategies.

The creation and support of "clearing houses", institutions or groups that bring together "seekers and providers" of goods, services or raw information/data, are recommended. Data sharing both nationally 
Table I. Global policy and legislative frameworks for invertebrate conservation and their impact and use in bee conservation strategy.

\begin{tabular}{|c|c|c|c|c|}
\hline $\begin{array}{l}\text { Policy or } \\
\text { framework name }\end{array}$ & Year est. & Function & $\begin{array}{l}\text { Impact in bee } \\
\text { conservation }\end{array}$ & $\begin{array}{l}\text { Potential impact on } \\
\text { bee conservation }\end{array}$ \\
\hline $\begin{array}{l}\text { International } \\
\text { Pollinator } \\
\text { Initiative (CBD) }\end{array}$ & 2000 & $\begin{array}{l}\text { To promote coordinated } \\
\text { action worldwide to: } \\
\text { Monitor, improve } \\
\text { taxonomic capacity of, } \\
\text { evaluate economically and } \\
\text { promote the conservation } \\
\text { of pollinators and } \\
\text { pollination }\end{array}$ & $\begin{array}{l}\text { Majority of effective } \\
\text { pollinators worldwide } \\
\text { are bees ( } 19500 \text { spp.), } \\
\text { thus this is the guiding } \\
\text { initiative in global } \\
\text { coordinated bee } \\
\text { conservation actions } \\
\text { and policys }\end{array}$ & $\begin{array}{l}\text { Continued implemen- } \\
\text { tation of their plan } \\
\text { of action }\end{array}$ \\
\hline $\begin{array}{l}\text { Agricultural } \\
\text { Biodiversity Work } \\
\text { programme } \\
\text { (CBD) }\end{array}$ & 1996 & $\begin{array}{l}\text { To promote the positive } \\
\text { effects and mitigate the } \\
\text { negative impacts of } \\
\text { agricultural systems and } \\
\text { practices on biological } \\
\text { diversity in } \\
\text { agro-ecosystems and their } \\
\text { interface with other } \\
\text { ecosystems }\end{array}$ & $\begin{array}{l}\text { Programme under } \\
\text { which the International } \\
\text { Pollinator Initiative } \\
\text { (IPI) was devised and } \\
\text { implemented }\end{array}$ & $\begin{array}{l}\text { Continued support } \\
\text { of the IPI and } \\
\text { integration of bee } \\
\text { friendly policies into } \\
\text { broader agricultural } \\
\text { strategies }\end{array}$ \\
\hline $\begin{array}{l}\text { Convention on } \\
\text { Biological } \\
\text { Diversity (CBD) }\end{array}$ & 1992 & $\begin{array}{l}\text { Conservation of } \\
\text { biodiversity, sustainable } \\
\text { use and sharing of benefits } \\
\text { from biodiversity related } \\
\text { resources }\end{array}$ & $\begin{array}{l}\text { Ultimate global policy } \\
\text { framework from which } \\
\text { legislation and other } \\
\text { activities can be } \\
\text { derived or supported }\end{array}$ & $\begin{array}{l}\text { Continued support } \\
\text { and implementation } \\
\text { of IPI, Agricultural } \\
\text { Biodiversity } \\
\text { Programme and } \\
\text { national reporting }\end{array}$ \\
\hline $\begin{array}{l}\text { Convention on } \\
\text { International } \\
\text { Trade in } \\
\text { Endangered } \\
\text { Species of Wild } \\
\text { Fauna and Flora } \\
\text { (CITES) }\end{array}$ & 1973 & $\begin{array}{l}\text { Regulation of commercial } \\
\text { trade in species in danger } \\
\text { of extinction }\end{array}$ & $\begin{array}{l}\text { Has invertebrates } \\
\text { including some } \\
\text { pollinators but no bees } \\
\text { are afforded protection, } \\
\text { as of yet }\end{array}$ & $\begin{array}{l}\text { Invasive bee } \\
\text { introductions (e.g. } \\
\text { Bombus terrestris) } \\
\text { through trade consid- } \\
\text { ered a problem for } \\
\text { native pollinators but } \\
\text { a regional issue } \\
\text { (Eardley et al., 2006) }\end{array}$ \\
\hline $\begin{array}{l}\text { The World } \\
\text { Heritage } \\
\text { Convention } \\
\text { (UNESCO) }\end{array}$ & 1972 & $\begin{array}{l}\text { Designation and } \\
\text { protection of World } \\
\text { Heritage Sites (sites of } \\
\text { outstanding cultural } \\
\text { and/or natural value) }\end{array}$ & $\begin{array}{l}\text { Protection of important } \\
\text { sites that maybe } \\
\text { significant bee habitat } \\
\text { e.g. the Burren region, } \\
\text { Ireland, which is on the } \\
\text { tentative list }\end{array}$ & $\begin{array}{l}\text { International frame- } \\
\text { work encourages } \\
\text { management plan } \\
\text { creation for the sites, } \\
\text { bee habitat manage- } \\
\text { ment could be incor- } \\
\text { porated }\end{array}$ \\
\hline $\begin{array}{l}\text { The Convention } \\
\text { on the } \\
\text { Conservation of } \\
\text { Migratory Species } \\
\text { of Wild Animals } \\
\text { (CMS or Bonn } \\
\text { Convention) }\end{array}$ & 1971 & $\begin{array}{l}\text { The conservation of } \\
\text { migratory species } \\
\text { throughout their range }\end{array}$ & $\begin{array}{l}\text { No bees are listed in } \\
\text { the Annexes, as of yet }\end{array}$ & $\begin{array}{l}\text { This convention has } \\
\text { limited potential for } \\
\text { bee conservation, } \\
\text { though bees may } \\
\text { indirectly benefit } \\
\text { in the protection of } \\
\text { other listed pollina- } \\
\text { tor's habitats (e.g. } \\
\text { Monarch Butterfly) }\end{array}$ \\
\hline
\end{tabular}


Table I. Continued.

\begin{tabular}{|c|c|c|c|c|}
\hline $\begin{array}{l}\text { Policy or } \\
\text { framework name }\end{array}$ & Year est. & Function & $\begin{array}{l}\text { Impact in bee } \\
\text { conservation }\end{array}$ & $\begin{array}{l}\text { Potential impact on } \\
\text { bee conservation }\end{array}$ \\
\hline $\begin{array}{l}\text { The Convention } \\
\text { on Wetlands of } \\
\text { International } \\
\text { Importance } \\
\text { (Ramsar } \\
\text { Convention) }\end{array}$ & 1971 & $\begin{array}{l}\text { The conservation and } \\
\text { wise use of all wetlands } \\
\text { through local, regional } \\
\text { and national actions and } \\
\text { international cooperation, } \\
\text { as a contribution towards } \\
\text { achieving sustainable } \\
\text { development }\end{array}$ & $\begin{array}{l}\text { Indirect protection at } \\
\text { riparian habitat sites }\end{array}$ & $\begin{array}{l}\text { Protection of } \\
\text { potential resource } \\
\text { rich habitats for bees. } \\
\text { Wetland areas can } \\
\text { contain important } \\
\text { wild forage sources } \\
\text { for bees (Sanford, } \\
\text { 1985; Leong and } \\
\text { Thorp, 2005) }\end{array}$ \\
\hline $\begin{array}{l}\text { UNESCO Man } \\
\text { and the Biosphere } \\
\text { programme } \\
\text { (MAB) }\end{array}$ & 1970 & $\begin{array}{l}\text { Proposes an } \\
\text { interdisciplinary research } \\
\text { agenda and capacity } \\
\text { building aiming to } \\
\text { improve the relationship } \\
\text { of people with their } \\
\text { environment globally. } \\
\text { It targets the ecological, } \\
\text { social and economic } \\
\text { dimensions of biodiversity } \\
\text { loss and the reduction of } \\
\text { this loss }\end{array}$ & $\begin{array}{l}\text { Indirect protection at } \\
\text { sites, ecosystem } \\
\text { service research }\end{array}$ & $\begin{array}{l}\text { Affords potential } \\
\text { of protection at MAB } \\
\text { sites and the develop- } \\
\text { ment of research } \\
\text { activities and infor- } \\
\text { mation sharing for } \\
\text { bee conservation }\end{array}$ \\
\hline $\begin{array}{l}\text { International } \\
\text { Union for } \\
\text { Conservation of } \\
\text { Nature (IUCN) }\end{array}$ & 1948 & $\begin{array}{l}\text { Supports scientific } \\
\text { research, manages field } \\
\text { projects and brings } \\
\text { governments, NGOs, } \\
\text { United Nations agencies, } \\
\text { companies and local } \\
\text { communities together to } \\
\text { develop and implement } \\
\text { environmental policy, } \\
\text { laws and best practice }\end{array}$ & $\begin{array}{l}\text { Facilitates the Species } \\
\text { Survival Commission } \\
\text { (SSC). Guides bee red } \\
\text { listing exercises at } \\
\text { regional and national } \\
\text { levels e.g. Sárospataki } \\
\text { et al. (2005), } \\
\text { Fitzpatrick et al. } \\
\text { (2006) }\end{array}$ & $\begin{array}{l}\text { Continued coordina- } \\
\text { tion of the Global } \\
\text { Red List and support } \\
\text { and guidance to Re- } \\
\text { gional and National } \\
\text { Red Lists }\end{array}$ \\
\hline $\begin{array}{l}\text { Species Survival } \\
\text { Commission } \\
\text { (SSC) programme } \\
\text { (IUCN) }\end{array}$ & 1948 & $\begin{array}{l}\text { It implements global } \\
\text { species conservation } \\
\text { initiatives, including Red } \\
\text { List Biodiversity } \\
\text { Assessment projects to } \\
\text { assess the status of species } \\
\text { for the IUCN Red List }\end{array}$ & $\begin{array}{l}\text { One globally listed bee } \\
\text { (Chalicodoma pluto), } \\
\text { though not designated } \\
\text { a threat status but data } \\
\text { deficient (DD) }\end{array}$ & $\begin{array}{l}\text { High potential for } \\
\text { greatly threatened } \\
\text { and endemic species } \\
\text { to be included, if } \\
\text { assessments and data } \\
\text { are available }\end{array}$ \\
\hline
\end{tabular}

and internationally through clearing houses for the benefit of informing policy makers is a major priority within the IPI-POA.

\subsection{IPI regional policy}

The Global IPI currently has five regional representative IPI's, put together by The São Paulo Declaration forum: the African Pollinator Initiative (API, see Eardley et al., 2009), Brazilian Pollinator Initiative (BPI), the European Pollinator Initiative (EPI), the North American Pollinator Protection Campaign (NAPPC) and the International Centre for Integrated Mountain Development (ICIMOD) $)^{1}$. A local chapter of the IPI has recently been proposed in Australia (August 2006); the Oceania Pollinator Initiative (OPI).

${ }^{1}$ A development organisation representing 8 countries of the Hindu Kush-Himalayas (HKH) mountainous region across the Eurasian continent (see: www.icimod.org). 
It is being discussed with FAO-IPI representatives (March 2007) and will represent a very large biogeographic region including Australia, New Zealand, New Guinea and other South Pacific Islands (http://www. oceaniapollinator.org).

The rationale behind the regional initiatives is the need for a collective approach towards implementing and developing the plans set out in the IPI-POA, to create regional networks. Expertise can be one of the limiting factors in conservation efforts, but can be minimised when countries take a collective approach to the conservation of bees (Eardley, 2001). Thematic issues set out in the IPI-POA need to be addressed on an international, regional or continental scale. Regional initiatives establish contact networks that can coordinate local interests and link them to regional activities. Other roles are to develop databases of expertise which are collected on a regional basis and compiled centrally (Potts, 2004). The European Pollinator Initiative has used this idea to facilitate links between experts in different fields and provide a look-up service for those people seeking specific advice or skilled input (Potts, 2004). A similar internet based network has been developed in the University of Guelph, Canada, called International Network of Expertise for Sustainable Pollination (Tang et al., 2005).

\subsubsection{African Pollinator Initiative (API) - A case study of a regional initiative in bee conservation}

The African Pollinator initiative was the first regional international pollinator initiative, and preceded the official formation of the IPI (Anon., 2001; see Eardley et al., 2009). COP6 met in the Hague, the Netherlands, in 2002 and one of the decisions it adopted was to welcome "the efforts to establish the African Pollinator Initiative, in the framework of the IPI" (Paragraph 10; www.biodiv.org/descisions). Subsequently the United Nations FAO officially adopted the API as the regional network for IPI and, because of the proactive approach to de- velopment, it became a model for implementation of IPI elsewhere. It will be used here as a case study for regional IPIs.

The African Pollinator Initiative (API) was established in January 1999 at the inaugural congress of the Southern African Society for Systematic Biology (SASSB) in Stellenbosch, South Africa (Anon., 2001). There are 15 countries involved, which are more than in any of the other regional pollinator initiatives, and they are divided into North, South, East and West areas with individual area coordinators (Kwapong, 2006). The API has developed a regional POA through an international workshop (Nairobi, 2002) and, with it, a steering committee to oversee its progress.

\subsubsection{Scope of the API}

The API contributes to the implementation of global conservation policy that takes a whole ecosystem approach to terrestrial ecosystem conservation. It achieves this through the group effort of individuals and organisations working together towards realistic goals (Anon., 2001). The API utilises pre-existing networks in the African continent currently involved in the Bio-NET international (an international non-profit organisation facilitating cooperation and collaboration between taxonomists), including EAFRINET (East Africa), WAFRINET (West Africa) and SAFRINET (Southern African Development Community). The API is a regional outlet for the publication of case studies, with the problem, cause and solution clearly highlighted for development of other successful strategies (Kwapong, 2006). The initiative controls development of standardised monitoring methods, thus avoiding duplication of effort across the region. Ultimately the API is a vehicle for the development and mainstreaming of effective policy. The API recognises that effective field activities, such as changes in management or agricultural practice, will be governed by national policies. 


\subsubsection{Some practical outcomes of the API}

The API has succeeded in implementing a number of practical initiatives within the region (reviewed in Eardley et al., 2009). In research and education, $\mathrm{PhD}$ programmes were initiated on crop pollination (Ghana) and bee taxonomy (South Africa) and a master's project researching stingless bees (Ghana); the API facilitates networking amongst these researchers (Kwapong, 2006). The API has supported a project on the utilisation of stingless bees (meliponine bees) for pollination and hive production in local communities in Kakum National Park, Ghana (Kwapong, 2006). The pilot project has shown a change in farmer behaviour with increased utilisation of bees for their services and products (wax, honey, medicine, pollination of crops) (Kwapong, 2008). The API plans to extend this project internationally with proposals for meliponiculture in Kenya, Ghana and Botswana (Mbengashe, 2006; Kwapong, 2008). An International Stingless Bee Centre (ISBC) has been established in Ghana for research, training and support of stingless bee husbandry in West Africa (Kwapong, 2008).

Capacity building initiatives have been successful thus far in a number of cases. Rodger et al. (2004) have provided a literature review of pollination biology in Africa, including thematic and geographic analyses (Eardley et al., 2006). The National Museums of Kenya and BIOTA East Africa hosted an Afrotropical bee genera identification and pollination research techniques course in 2006 (Kwapong, 2006). Kenya has capacity in regards to taxonomy and training and utilises API to build links with other interested parties and countries regionally (Kwapong, 2006; Gikungu, 2008). The National Museums of Kenya (NMK) have started digitising all invertebrate data from their collections, with a further plant-pollinator database in development. The NMK has created a Pollination Ecology and Bee Taxonomy Centre, developed parataxonomist courses, promoted meliponiculture and apiculture and established pollinator gardens (Gikungu, 2008). There has also been taxonomic progress with the revisions of some African genera of megachilid bees (Danforth and Griswald, 2008).

\section{OTHER INITIATIVES}

\subsection{IUCN red data listing}

The International Union for Conservation of Nature (IUCN), through its Species Survival Commission (SSC), has for more than four decades been assessing the conservation status of species on a global scale in order to highlight taxa threatened with extinction, and therefore promote their conservation (http://www.iucnredlist.org/info). To this end the commission produces a Global Red List, which includes the listing of globally threatened species. Thus far, no bee species have a threat status designation. One species is present on the global list, Wallace's Giant Bee, Chalicodoma pluto, as Data Deficient (DD) (1994; http://www.iucnredlist. org/search/details.php/4410/all) which means there is not enough information on its distribution and/or abundance to make an objective evaluation of threat to it. The DD designation highlights the need for further research to give a true assessment. The IUCN Global Red List does not hold legislative weight but does make objective assessments of threat status that can be a powerful tool for conservation planning, management, monitoring and decision making (Rodrigues et al., 2006).

\subsubsection{Regional and National Red Lists and Priority Lists}

At the global level, the World Conservation Union (IUCN) has played a central role in the development of assessments of extinction risk across animal and plant taxa, through the use of their red list system (IUCN, 2001, 2006). More recently the IUCN developed protocols for the development of regional assessments (IUCN, 2003) which has resulted in the production of regional, national and local red lists for taxa irrespective of the extent to which they have been assessed at the global level (e.g., Samways, 2002; Gärdenfors, 2005; Broughton 
and McAdam, 2002). The IUCN provide standardised guidelines for the development of red lists but do not endorse the lists published below the global level, instead suggesting that they be accepted and published by the relevant regional or national authority (IUCN, 2003). Although they hold no legislative weight, at national levels they are an important policy mechanism that can be effectively applied to bees (e.g., Sárospataki et al., 2005, Hungary; Fitzpatrick et al., 2006, Ireland).

The IUCN recently developed a set of standard terms (Conservation Actions Authority File; see www.iucnredlist.org/info/ conservation_actions) for documenting taxa on a Red List to ensure global uniformity when describing what conservation measures are in place or are needed. This hierarchical classification of conservation actions allows assessors to indicate the conservation actions that are needed for each taxon and that could be achieved realistically in approximately the next 5 years. This file has been used at national levels to indicate the actions necessary for red listed bees (e.g., Fitzpatrick et al., 2006).

While a regional Red List provides an important objective assessment of regional extinction risk, it is not the same as a list of conservation priorities (Gärdenfors, 2001; Gärdenfors et al., 2001; Possingham et al., 2002; IUCN, 2003; Keller and Bollmann, 2004; Rodrigues et al., 2006; Fitzpatrick et al., 2007). Setting priorities for conservation is a distinct and broader process (Mace and Lande, 1991) that should consider financial, cultural, logistical, biological, ethical, and social factors in addition to extinction risk (Miller et al., 2006). A standardised methodology was proposed by Fitzpatrick et al. (2007) for building on a regional or national Red List to create a national list of conservation priority species using bees as a model.

At national levels, the combination of creating an IUCN Red List (objective threat statuses), a Conservation Actions Authority File (essential actions to be taken) and a list of priorities for conservation action (identify which animals should acquire the actions) can give guidance to governmental or other organisa- tions with respect to national bee conservation policies.

\subsection{European regional legislation}

Europe is unusual in the fact that there is legislation in place that works supranationally across a region. At this regional level general conservation policies exist that can impact on bee conservation indirectly through habitat protection, the creation of reserves and parks, and conservation networks that extend transnationally. There are a number of pieces of legislation of this type (e.g. the Bern Convention), one important law being the EU Habitats Directive which was set-up as a policy instrument to designate Special Areas of Conservation (SACs). The SACs are assigned as a result of the presence of an Annex I listed habitat type(s) or an Annex II listed species (Haslett, 2007). There are no bees listed as of yet in Annex II list, nor are there any Hymenoptera in general, however a number of important natural bee habitat types are protected (Rasmont, 1995). The habitats directive is a binding legislative agreement and member states not fulfilling their legal requirements can be penalised through the EU.

Other current regional policies that are incentives to sustainable land use do not target bees specifically, but do have knock on benefits for their conservation e.g. the AgriEnvironmental Schemes in the EU have encouraged farmers to carry out environmentally beneficial activities on their lands to enhance biological diversity, with costs being compensated through state payments (Eardley et al., 2006). This regional policy has affected farming practices in over 900000 farms across the EU and has benefitted bees through a number of favourable incentives e.g. preservation of historical features such as hedgerows.

\subsection{NBSAPs and CBD national reporting}

Most policy frameworks at the national level come in the form of National Biodiversity Strategies and Action Plans (NBSAPs); 
these have been, or are currently being developed, by each party to the CBD and provide a framework for action to deliver national commitments to the conservation and sustainable use of biodiversity, including bees (Haslett, 2007). The IPI-POA highlights the importance of the integration of pollination and pollinators into these NBSAPs (Eardley et al., 2006). The progress of the parties to the CBD is assessed through a national reporting system (Article 26) where an assessment of the measures taken to implement the convention is made. As countries have to report on progress made under the programme of work on agricultural biodiversity, specifically the implementation of the IPI-POA (Box LXV and Question 163 of the 3rd report to the CBD), bees can be mainstreamed into national policy. This reporting system could be used to identify problems or gaps in bee conservation action to be improved upon at national levels and thus can be a mechanism for reiterative pollinator policy and action review.

In the UK, as part of their strategy on biodiversity conservation, a species Biodiversity Action Plan (BAP) system (UK BAP) has been created, principally for invertebrates (Holloway et al., 2003). Three types of Action Plans (species action plans, habitat action plans and local action plans) have been developed which set priorities for nationally and locally important habitats and wildlife. There are 382 species with priority action plans, 17 of which are bee species (http://www.ukbap. org.uk/species.aspx). These bee action plans have costed actions and targets and reporting on these targets is done on a 3-5 year cycle, and so the plans have direct conservation significance for bee populations.

\subsection{Other national legislation}

National statutory legislation with regards to wildlife and habitats may exist that is not directly affected, or imposed, by global or regional policy initiatives. These state legislations often regulate the exploitation of habitats and species within a nation state, and thus could be used to mainstream bees into policy. In the Republic of Ireland, for example, the principal piece of legislation impacting on fauna is the Wildlife Act (1976, 2000). This act of legislation affords protection to a number of faunal groups, though no bees are currently listed for protection. The act also enables protection of areas of particular importance for wildlife and certain habitats through the creation of nature reserves and National Heritage Areas (NHAs) which may indirectly impact bee conservation.

Tang et al. (2005) reviewed the federal and provincial 'hard' legislation (binding statutes) in Canada in relation to insect pollinators. They showed there was indirect protection of this group though no explicit or specific pollinator federal legislation existed. However, there were a number of hard protection laws pertaining to managed, introduced bees at the provincial level but they are limited in their capacity to protect wild, native bee pollinators (Tang et al., 2005). Two new acts (the Pollinator Protection Act (2007) and the Pollinator Habitat Protection Act (2007)) have been introduced in the United States that could have direct impact on bee conservation for both wild and managed species (The Xerces Society for Invertebrate Conservation, 2008). The acts would increase funding for research into Colony Collapse Disorder (CCD) in honey bees, parasites, pathogens, toxins, and other environmental factors that affect honey bees and native bees; support research into the biology of native bees and their capacity for crop pollination; and reduce the loss of bee habitat (Black, 2007). These acts have been introduced to the US Senate but have not yet been made legally binding. Some European Countries (Poland and Germany) and districts (Paris) have protective legislation for some or all bees (Rasmont, 1995). In Germany, for example, all wild bees are protected by law (Bundesgesetzblatt 22.12.72) so all destructive activities that result in bee deaths are illegal. However this type of blanket protection has been criticised as being ineffective as there is no conceivable way to enforce the law in full (Rasmont, 1995).

\section{DISCUSSION}

Global, regional and national frameworks exist for the actual, or potential, conservation 


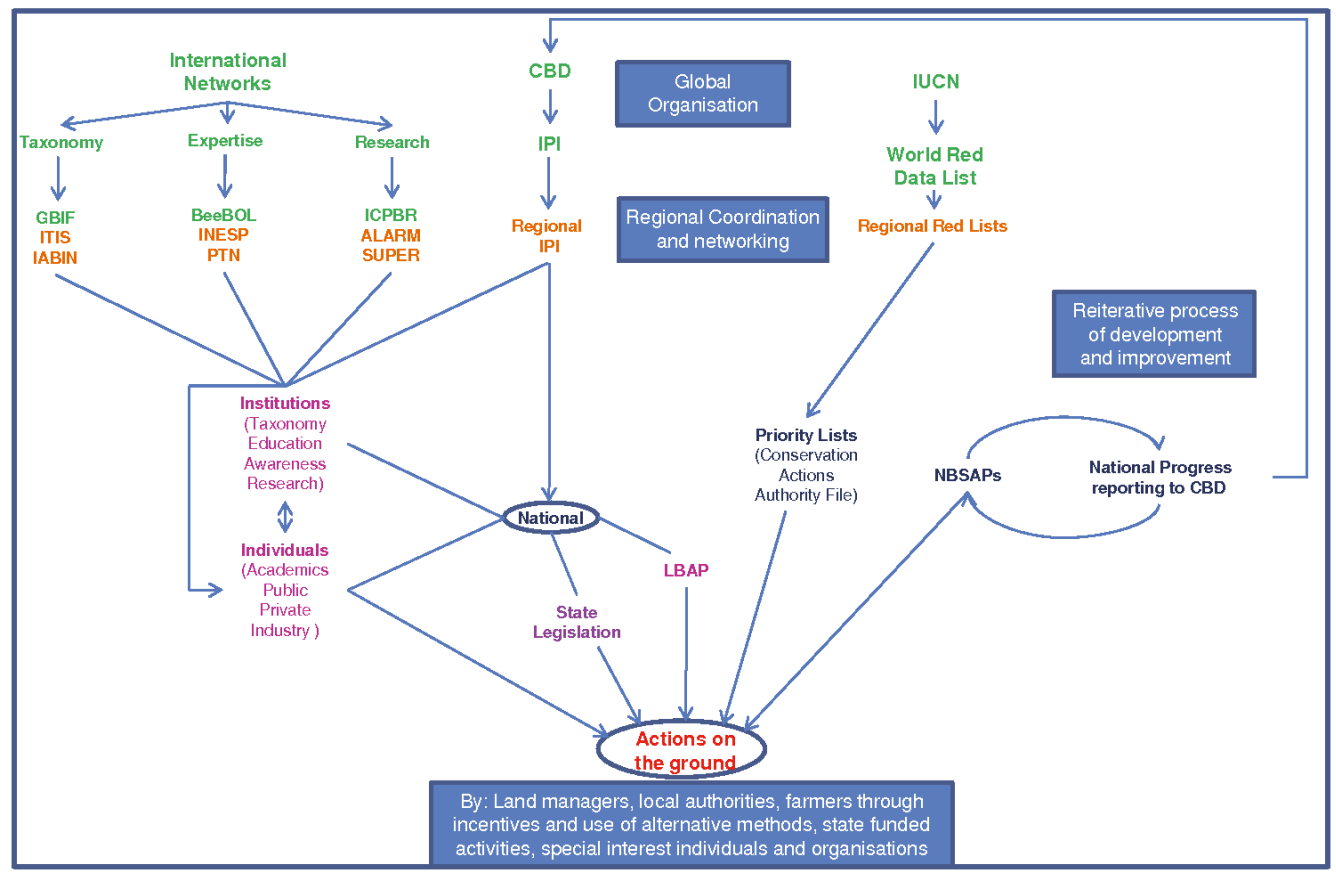

Figure 1. Schematic diagram showing the main global (green), regional (orange), national (blue) and subnational (pink) policies and legislation impacting on bee conservation. The International Pollinator Initiative (IPI) is a cross-cutting initiative within the Convention on Biological Diversity (CBD) which has a number of regional initiatives (regional IPI). Progress on National Biodiversity Strategies and Action Plans (NBSAPs) are reported to the CBD (next report due 2009); this reporting system can be used to identify problems or gaps to be improved upon at national levels. Local biodiversity action plans (LBAPs) can also include actions for bees. The IUCN oversees and give guidance to the Global Red List and Regional Red Lists processes. Regional Red Lists can impact conservation efforts directly on the ground through the creation of Conservation Action Authority Files from Priority lists. Examples of international networks impacting bee conservation are listed below. These networks link and support institutions and individuals with interests in bee conservation. Most actions on the ground come through national and local mechanisms under guidance, implementation and/or funding from higher level initiatives. (GBIF: Global Biodiversity Information Facility; ITIS: Integrated Taxonomic Information System; IABIN: Inter-American Biodiversity Information Network; Bee-BOL: Bee-Barcode of Life; INESP: International Network of Expertise for Sustainable Pollination; PTN: Pollinators Thematic Network; ICPBR: International Commission for PlantBee Relationships; ALARM: Assessing Large-scale Risks to biodiversity with tested Methods; SUPER: Sustainable Use of Pollinators as a European Resource).

of bees (see Fig. 1 for the framework summary). The global framework is fundamentally governed by the Convention on Biological Diversity (CBD) through the auspices of the International Pollinator Initiative (IPI). A functioning regional policy framework is in existence in the form of the Regional IPIs. There are also regional legislative frameworks pertaining to the conservation of biodiver- sity at transnational levels (i.e. the Council of Europe). These global and regional frameworks have strong links and work well together in terms of policy integration and dissemination of information amongst the different stakeholders. Regional IPIs are representatives of the CBD-IPI and so mirror fundamental elements of the global IPI Plan of Action. Regional conservation legislation 
also fundamentally reflects the CBD (Haslett, 2007), thus allowing effective interaction at these different policy levels.

Problems may arise when global and regional frameworks are not made accessible to stakeholders at the national or subnational level. At these levels, knowledge and utilisation of the pre-existing frameworks may aid in the development of policies and practices. We suggest that greater emphasis is placed on developing mechanisms which improve dissemination of information throughout the system, linking the policies and policymakers with other important stakeholders (e.g. bee conservationists, pollination scientists, farmers, planners etc.). Projects such as the creation of the pollinator policy and practice handbook (Eardley et al., 2006) and strategies such as the European Strategy for the Conservation of Invertebrates (Haslett, 2007) should be supported and encouraged for their efforts to bridge these gaps. Other networks involving bee taxonomy (e.g. Global Bee Checklist, GBIF), expertise (e.g. INESP, Pollinator Thematic Network (PTN)) and research (e.g. ICPBR and ALARM) should also be commended (see Fig. 1) and supported, whilst highlighting the effectiveness of information technology (IT) and the internet as a medium for the exchange of ideas and dissemination of information.

A second main challenge is in ensuring that mechanisms can interact effectively at national levels, considering the myriad of different national situations there will be with respect to bee conservation and its perceived importance. This second issue is one of policy integration. The European Strategy for the Conservation of Invertebrates (Haslett, 2007) has been adopted by the Council of Europe (Bern Convention) and addresses the loss of terrestrial and freshwater invertebrate biodiversity (including bees) and promotes their conservation and the services they provide (i.e. for bees: pollination). This strategy fits into existing European conservation policy and integrates into the global CBD, while designed to give guidance to national governments, land managers, scientists and other individuals and groups. This type of strategy is essential amongst the different policy frameworks to ensure dissem- ination of information, for policy integration and to avoid duplication of effort and ambiguity of policy. A further element in successful policy frameworks is the integration of preexisting statute laws with regional or global initiatives. One example of this is the Wildlife (Amendment) Act (2000) of the Republic of Ireland. This amended law integrated CITES and gave statutory recognition of the CBD in Irish law. We support such amendments that give global or regional initiatives more weight in individual national legislation for the protection of bees and encourage further such amendments to national policies.

The perceived economic value of bee species can impact on whether a species is specifically protected or not in legislation. For example, in Canada provincial legislation for the protection of bees is primarily based around the protection of domesticated nonnative bee species (e.g. Megachile rotunda and Apis millifera) for their pollination services of specific crops such as Alfalfa, and does not provide protection of wild native species (Tang et al., 2005). We concur with Tang et al.'s (2005) suggestion that laws pertaining to managed bee species should be altered, or bee terminology within the Acts be changed to include additional wild bee species. Rasmont (1995) criticises blanket protection on all bee species as being ineffectual, instead arguing that smaller lists of rare, readily identifiable, indicator species be protected through legal annexes (it is worth noting that National and Regional Red Lists and Priority Lists lend themselves to this sort of bee protection policy development). Rasmont (1995) also suggests that effectual broad ranging protection for bee populations would be best served through protection of bee habitats, reiterating the value of direct (e.g. Pollinator Habitat Protection Act 2007, USA) and indirect habitat protection policies (e.g. Habitats Directive Annex I, EU). In the United States two recent bills have been introduced, the Pollinator Protection Act (2007) and the Pollinator Habitat Protection Act (2007), that will provide funding for research and protection for bees (The Xerces Society for Invertebrate Conservation, 2008). These Acts have been primarily proposed because of reduced crop yields due to pollinator 
decline; a pollination service which has been valued at $\$ 14.6$ billion (Morse and Calderone, 2000). An encouraging element of the Acts is that they will incorporate wild native pollinators as well as managed species. If these acts are ratified into legislation it would be a major step in the conservation of bees in the United States. Native bee pollinators are being recognised more for their free ecological service they provide (The Xerces Society for Invertebrate Conservation, 2008) and, thus, should be incorporated more into legislation. Native pollinators alone have been valued at $\$ 3$ billion to the US economy (Losey and Vaughan, 2006) and have been shown to be particularly important pollinators in tropical crops where there have been declines in managed bees (Ricketts, 2004). Specific and targeted bee legislation should be incorporated (mainstreamed) into pre-existing national statutes or new statutes developed. However this maybe more likely in countries where insect pollinated crops are of particular importance to the national economy. Despite this, we reiterate the message of the IPI-POA with regards to integrating (adding species to legislative annexes) bees into national, or regional in the case of Europe, legislation. Legally binding protection of listed species is one of the most effective ways to safeguard vulnerable or important populations.

With only one globally red-listed bee species, even though there are believed to be over 19500 species in existence (Ascher et al., 2008; Michener, 2000), the global redlist is not yet a very useful framework in the conservation of bees. Some species could be proposed readily, for example Frankin's Bumblebee, Bombus franklini of California, which exhibits extreme endemism and documented decline (Williams, 1998; Thorp, 2005; Williams and Osborne, 2009), but is yet to be included. The Global Red List has been criticised in general for invertebrate representation, as only $33 \%$ of the endangered species are invertebrates even though the group represents $94 \%$ of the total animal biodiversity of the planet (Black et al., 2001). It has been highlighted that there is a discrepancy between regional lists and the global list, as endemic species on Regional Red Lists (RRLs) often are not listed on the world Red List, leading to scepticism of the value of RRLs (Rodriguez et al., 2000). Developing a method for incorporating national/regional assessments into global assessments is a vital next step (Miller et al., 2005), especially for a group, such as bees, that is so grossly underrepresented in the Global Red List. Bee species could be considered for inclusion on the Global Red List. However until this process has been completed Red Lists at lower geographic or political scales should be utilised. Indeed, RRLs may be more useful tools for species conservation (Rodrigues et al., 2000); they can be used at subnational (e.g. Leth, 1997), national (e.g. Sárospataki et al., 2005) and regional scales (e.g. Shepherd et al., 2005).

Other non-legislative mechanisms that afford protection to species or habitats are of particular importance in pollinator conservation (Eardley et al., 2006). Nationally identifying bee species extinction risk (production of Red Data Lists) and prioritising them into a list of conservation concern (Priority list) is an essential step in the process of affording protection to bees at the national level. These activities could allow for the inclusion of bees into national policy and legislation, particularly in countries that are still formalising their commitments into National Biodiversity regulations since the adoption of the CBD (Eardley et al., 2006).

In summary, we recommend the further development of mechanisms that allow for the efficient dissemination of relevant bee conservation information through the different policy levels to stakeholders. Making stakeholders at national and subnational levels fully aware of existing global and regional policy initiatives is highlighted as a priority. We support and encourage the development of taxonomic expertise and research networks, and the sharing of ideas, with the effective utilisation of the internet. We also recommend that, within regional initiatives, greater emphasis is placed on providing stakeholders at national and subnational levels with advice on how national legislation can integrate effectively into existing global and regional policy frameworks for the conservation of bees.

Where bee protection policies exist, policies should be expanded to protect wild bees 
due to the pollination services they provide and not just to support managed species. We would encourage further research and evaluation of bee species that may be afforded protection through the Global Red List, and the development of Regional Red Lists and Priority lists to establish actions for nationally or regionally threatened species. Implementation of some or all of these recommendations could improve significantly the chance of halting the decline of bees and the essential ecosystem service they provide.

\section{ACKNOWLEDGEMENTS}

We would like to thank the National Biodiversity Data Centre, Ireland, their funders, the Heritage Council of Ireland, and Dr. Liam Lysaght for the support during the writing of this paper and two anonymous reviewers for their comments.

La politique de conservation des abeilles aux niveaux mondial, régional et national.

Apoidea / abeille / politique / protection / législation / initiative internationale sur les pollinisateurs

\section{Zusammenfassung - Richtlinien zum Schutz der} Bienen auf globaler, regionaler und nationaler Ebene. Bienen sind unter den Insekten die am höchsten entwickelten und effektivsten Bestäuber für mehr als $70 \%$ aller Blütenpflanzen. Sie stellen damit eine ökologisch und ökonomisch unverzichtbare Gruppe zur Aufrechterhaltung des Ökosystems dar. Inzwischen gibt es zahlreiche Belege für einen weit verbreiteten Rückgang der Bienen, was zur Bildung von globalen, regionalen und nationalen Regelungen zum Schutz der Bienen geführt hat. Es gibt zwei zentrale Ansatzpunkte für globale Regelwerke zum Schutz der Bienen (Details siehe Tab. I). Die weltweite Rote Liste gefährdeter Arten, aufgestellt von der Weltnaturschutzunion (International Union for Conservation of Nature), hat nur einen begrenzten Effekt für den Bienenschutz, da bisher keiner Bienenart der Status als gefährdete Tierart zugesprochen wurde. Das wichtigste Rahmenwerk zum Schutz der Bienen ist die Internationale Bestäuberinitiative (International Pollinator Initiative, IPI), eine Querschnittsinitiative des Biodiversitätsabkommens (Convention of Biological Diversity, CBD). Die Hauptaufgabe der IPI ist es, vorgeschlagene Aktionen weltweit zu fördern und zu koordinieren und die IPI ist auch die globale Plattform, um Richtlinien zum Schutz der
Bestäuber, einschließlich Bienen, aufzustellen. Die IPI entwickelt einen Aktionsplan, um verbesserte Richtlinien und Ausführungsbestimmungen zum Schutz der Bienen und deren Habitate zu erreichen. Regional gibt es bereits allgemeine Regelwerke zum Naturschutz, die durch den Schutz von Habitaten und Ökosystemen positive Auswirkungen auf den Bienenschutz haben können; ein Beispiel ist die Fauna-Flora-Habitat-Richtlinie (FFH) in der Europäischen Union. Spezielle Richtlinien für den Bestäuberschutz werden vom IPI in Form regionaler Bestäuberinitiativen umgesetzt. Dadurch können Netzwerke über eine gesamte Region etabliert werden, was die Umsetzung von IPI-Aktionsplänen auf dieser regionalen Ebene erleichtert.

Auf der nationalen Ebene beeinflussen drei Rahmenrichtlinien den Bienenschutz. Während die weltweite Rote Liste nur einen begrenzten Einfluss auf den Bienenschutz hat, können regionale und nationale Rote Listen einen größeren Effekt haben, indem sie die Bedrohung der Bienen auf der regionaler bzw. nationaler Ebene feststellen und Schutzmassnahmen für bestimmte Arten aufstellen. Das CBD bietet durch die Aufstellung von nationalen Biodiversitätsabkommen und Aktionsplänen einen Rahmen, um nationale Verpflichtungen zum Schutz der Biodiversität abzugeben; sie kann daher für den Bienenschutz auf nationaler Ebene verwendet werden. Daneben können gesetzliche nationale Regelungen zum Schutz der Fauna eventuell auch für den Bienenschutz angewendet werden.

Für ein funktionierendes System (Abb. 1) empfehlen wir, dass die Informationen zu solchen Regelwerken veröffentlicht werden und für alle Interessierten zugänglich sind. Es sollten mehr Anstrengungen unternommen werden, um globale, regionale und nationale Regelungen zu verbinden. Regelungen, die bereits einen Schutz für Bienen bieten, sollten erweitert werden und nicht nur die vom Menschen gehaltenen Bienenarten sondern auch Wildbienen mit einbeziehen. Die weltweite Rote Liste sollte Bienen mit einbeziehen und damit deren Anzahl und Bedeutung gerecht werden. Wir empfehlen, dass regionale Rote Listen und Prioritätslisten entwickelt werden und dass auf dieser Basis entsprechende Schutzmaßnahmen etabliert werden. Die Umsetzung dieser Empfehlungen würde die Chance erhöhen, den Rückgang der Bienen zu stoppen und damit deren essentiellen Leistungen für das Ökosystem zu sichern.

Naturschutz / Richtlinien / Bienen / Internationale Bestäuberinitiative / Gesetzgebung / Apoidea

\section{REFERENCES}

Allen-Wardell, G., Bernhardt P., Bitner R., Burquez A., Buchmann, S., Cane J., Cox P.A, Dalton V., 
Feinsinger P., Ingram M., Inouye D., Jones C.E., Kennedy K., Kevan P., Koopowitz H., Medellin R., Medellin-Morales S., Nabhan G.P. (1998) The potential consequences of pollinator declines on the conservation of biodiversity and stability of food crop yields, Conserv. Biol. 12, 8-17.

ANON. (2001) Development of the African Pollinator Initiative, [online] http://www.iita. org/wafrinethome/PDFs/African\%20Pollinator\% 20Initiative.pdf (accessed on 12 February 2009).

Ascher J., Eardley C., Griswold T., Melo G., Polaszek A., Ruggiero M., Williams P., Walker K., Warrit N. (2008) World Bee Checklist Project - update 2008-09, manuscript (version 10/09/2008), [online] Integrated Taxonomic Information System. http://www.itis.gov/beechecklist.html (accessed on: 13 February 2009).

Biesmeijer J.C., Roberts S.P.M., Reemer M., Ohlemûller R., Edwards M., Peeters T., Schaffers A.P., Potts S.G., Kleukers R., Thomas C.D., Settele J., Kunin W.E. (2006) Parallel declines in pollinators and insect-pollinated plants in Britain and the Netherlands, Science 313, 351-354.

Black S.H. (2007) Pollinator Protection Act of 2007 Introduced into the U.S. Senate, The Xerces Society for Invertebrate Conservation, Portland, Oregon.

Black S.H., Shepard M., Allen M.M. (2001) Xerces Endangered Species Update, 18, 42-49.

Blanche K.R, Ludwig J.R., Cunningham S.A. (2006) Proximity to rainforest enhances pollination and fruit set in orchards, J. Appl. Ecol. 43, 1182-1187.

Broughton D.A., McAdam J.H. (2002) A red data list for the Falkland Islands vascular flora, Oryx 36, 279-287.

Buchmann S.L., Nabhan G.P. (1996) The Forgotten Pollinators, Island Press, Washington, DC.

Corbet S.A., Williams I.H., Osborne J.L. (1991) Bees and the pollination of crops and wild flowers in the European Community, Bee World 72, 47-59.

Danforth B.N., Sipes S., Fang J., Brady S.G. (2006) The history of early bee diversification based on five genes plus morphology, Proc. Natl. Acad. Sci. USA 103, 15118-15123.

Danforth B.N., Griswald, T. (2008) Megachilid Bees, Phylogenetic \& Revisionary Studies, [online] www.bee-bol.org/durban\%20pres/Griswold. ppt (accessed on: 13 February 2009).

Dias B.S.F., Raw A., Imperatriz-Fonseca V.L. (1999) International Pollinators Initiative: The Sao Paulo declaration on pollinators, Report on the Recommendations of the Workshop on the Conservation and Sustainable Use of Pollinators in Agriculture with Emphasis on Bees, [online] www.biodiv.org/doc/case-studies/ agr/cs-agr-pollinator-rpt.pdf (accessed on: 13 February 2009).
Eardley C.D. (2001) Pollinators: a conservation priority. Science in Africa, Issue 2, [online] http:// scienceinafrica.co.za/pollinator.htm (accessed on: 13 February 2009).

Eardley C., Roth D., Clarke J., Buchmann S., Gemmill B. (2006) Pollinators and pollination: A resource book for policy and practice, Publ. by African Pollinator Initiative (API), South Africa.

Eardley C., Gikungu M., Schwarz M.P. (2009) Bee conservation in sub-Saharan Africa and Madagascar: diversity, status and threats, Apidologie 40, 355-366.

Fitzpatrick Ú., Murray T.E., Byrne A., Paxton R.J., Brown M.J.F. (2006) Regional Red List of Irish Bees, Publ. Rep. to National Parks and Wildlife Service (Ireland) and Environment and Heritage Service (N. Ireland).

Fitzpatrick Ú., Murray T.E., Paxton R.J., Brown M.J.F. (2007) Building on IUCN Regional Red Lists to Produce Lists of Species of Conservation Priority: a Model with Irish Bees, Conserv. Biol. 21, 1324 1332.

Freitas B.M., Imperatriz-Fonseca V.L., Medina L.M., Kleinert A.M.P., Galetto L., Nates-Parra G., Quezada-Euán J.J.G. (2009) Diversity, threats and conservation of bees in the Neotropics, Apidologie $40,332-346$.

Gärdenfors U. (2001) Classifying threatened species at national versus global levels, Trends Ecol. Evol. $16,511-516$.

Gärdenfors U., Hilton-Taylor C., Mace G.M., Rodríguez J.P. (2001) The application of IUCN Red List criteria at regional levels, Conserv. Biol. 15, 1206-1212.

Gärdenfors U. (Ed.) (2005) Rädlistade arter i Sverige 2005 — the 2005 Red List of Swedish species. ArtDatabanken, The Swedish Species Information Centre, Uppsala.

Gikungu M. (2008) Status of Pollinator Studies in Kenya. Global Bee Summit, Durban South Africa, Workshop Presentation.

Goulson D. (2003) Effects of introduced bees on native ecosystems, Annu. Rev. Ecol. Evol. Syst. 34, 126.

Goulson D., Stout J.C., Kells A.R. (2002) Do exotic bumblebees and honeybees compete with native flower-visiting insects in Tasmania? J. Insect Conserv. 6, 179-189.

Haslett J.R. (2007) European strategy for the conservation of invertebrates, Nature and Environment, No. 145.

Holloway G.J., Griffiths G.H., Richardson P. (2003) Conservation strategy maps: a tool to facilitate biodiversity action planning illustrated using the heath fritillary butterfly, J. Appl. Ecol. 40, 413421. 
Imperatriz-Fonseca V.L., Dias B.F.S. (2004) Brazilian Pollinators Initiative. in: Freitas B.M., Pereira O.P. (Eds.), Solitary bees- conservation, rearing and management for pollination, UFC, pp. 27-34. [online] http://www.webbee.org.br/ bpi/english/solitary_bees.htm (accessed on 13 February 2009).

Ingram M., Nabhan G., Buchmann S. (1996) Our Forgotten Pollinators: Protecting the Birds and Bees, Global Pesticide Campaigner Volume 6, Number 4, December 1996, PANNA, San Francisco, CA, [online] http://www.pmac.net/ birdbee.htm (accessed on: 13 February 2009).

International Pollinator Initiative - Plan of Action (2002) Pollinators - Plan of Action, [online] http:// www.cbd.int/agro/planaction.shtml (accessed on: 13 February 2009).

IUCN (2001) IUCN Red List categories. Version 3.1. Species Survival Commission, IUCN, Gland, Switzerland, and Cambridge, United Kingdom.

IUCN (2003) Guidelines for application of IUCN Red List criteria at regional levels, Version 3.0. Species Survival Commission, IUCN, Gland, Switzerland, and Cambridge, United Kingdom.

IUCN (2006) Guidelines for using the IUCN Red List categories and criteria. Version 6.1. Species Survival Commission, IUCN, Gland, Switzerland, and Cambridge, United Kingdom.

Kearns C.A., Inouye, D.W., Waser, N.M. (1998) Endangered mutualisms: the conservation of plant-pollinator interactions, Annu. Rev. Ecol. Syst. 29, 83-112.

Keller V., Bollmann K. (2004) From red lists to species of conservation concern, Conserv. Biol. 18, 16361644.

Kremen C., Ricketts T. (2000) Global perspectives on pollination disruptions, Conserv. Biol. 14, 12261228.

Kremen C., Williams N.M., Bugg R.L., Fay J.P., Thorp R.W. (2004) The area requirements of an ecosystem service: crop pollination by native bee communities in California, Ecol. Lett. 7, 1109-1119.

Kwapong P. (2006) Benefits of Taxonomy: African Pollinator Initiative (API). Taxonomy for Ghana's development and conservation - assessing the needs, Ghana-UK project 2006-7, Workshop Presentation.

Kwapong P. (2008) African Pollinator Initiative (API). Global Bee Summit, Durban South Africa, Workshop Presentation.

Leong J.M., Thorp R.W. (2005) Bee Diversity Associated with Limnanthes Floral Patches in California Vernal Pool Habitats, USDA Forest Service Gen. Tech. Rep. PSW-GTR-195.

Leth P. (1997) Regional rødliste over særligt beskyttelseskrævende karplanter i Vestsjællands Amt 1997, Vestsjællands Amt, Natur \& Miljø. Sorø.
Losey J.E., Vaughan M. (2006) The economic value of ecological services provided by insects, BioScience 56, 311-323.

Mace G., Lande R. (1991) Assessing extinction threats: toward a reevaluation of IUCN threatened species categories, Conserv. Biol. 5, 148-157.

Mbengashe M. (2006) South Africa's third national report to the Convention on Biological Diversity, [online] http://www.cbd.int/doc/world/ za/za-nr-03-en.pdf (accessed on: 13 February 2009).

Michener C.D. (2000) The Bees of the World, John Hopkins University Press, Baltimore.

Miller R., Rodríguez J.P., Bambaradeniya C., Boles R., Eaton M., Fowler T., Gärdenfors U., Keller V., Molur S., Pollock C.,Walker S. (2005) Report from the National Red List Advisory Group Workshop "Analysis of the Application of IUCN Red List Criteria at a National Level" Villa Majagual, 21-26 January 2005.

Miller R.M., Rodríguez J.P., Aniskowicz-Fowler T., Bambaradeniya C., Boles R., Eaton M.A., Gärdenfors U., Keller V., Molur S., Walker S., Pollock C. (2006) Extinction risk and conservation priorities, Science 313, 441-441.

Morse R.A., Calderone N.W. (2000) The value of honey bees as pollinators of U.S. crops in 2000, Bee Culture 128, 15.

Murray T.E., Kuhlmann M., Potts S.G. (2009) Community ecology of bees: populations, species and communities, Apidologie 40, 211-236.

Pimentel D., Wilson C., McCullum C., Huang R., Dwen P., Flack J., Tran Q., Saltman T., Cliff B. (1997) Economics and environmental benefits of biodiversity, BioScience 47, 747-757.

Possingham H.P., Andelman S.J., Burgman M.A., Medellín R.A., Master L.L., Keith D.A. (2002) Limits to the use of threatened species lists, Trends Ecol. Evol. 17, 503-507.

Potts S.G. (2004) European Pollinator Initiative, Crop and Crop Associated Biodiversity Pollinator Case Studies, [online] http://www.fao.org/ag/ AGP/agps/C-CAB/Castudies/pdf/9-002.pdf (accessed on: 13 February 2009).

Rasmont P. (1995) How to restore the Apoid diversity in Belgium and France? Wrong and right ways, or the end of the protection paradigm! in: Banaszak J. (Ed.), Changes in European Bee Fauna, Pedagogical University, Bydgoszcz.

Remsen D., Ruggiero M. (2007) Towards a Global Bee Checklist: Summary and Status Report, [online] http://globalbees.editwebrevisions.info/ en/node/913 (accessed on: 13 February 2009).

Ricketts T.H. (2004) Tropical forest fragments enhance pollinator activity in nearby coffee crops, Conserv. Biol. 18, 1262-1271. 
Rodger J.G., Balkwill K., Gemmill B. (2004) African pollination studies: where are the gaps? Int. J. Trop. Insect Sci. 24, 5-28.

Rodrigues A.S.L., Pilgrim J.D., Lamoreux J.F., Hoffman M., Brooks T.M. (2006) The value of the IUCN Red List for conservation, Trends Ecol. Evol. 21, 71-76.

Rodriguez J.P., Ashenfelter G., Rojas-Suárez F., García Fernández J.J., Suárez L., Dobson A.P. (2000) Local data are vital to world-wide conservation, Nature 403, 241.

Sanford (1985) Wet Lands - The Bee forage Connection, APIS, 3 (6), June 1985, [online] http://apis.ifas.ufl.edu/apis85/apjun85.htm\#2 (accessed on: 13 February 2009).

Samways M.J. (2002) Red-listed Odonata of Africa, Odonatologica 31, 151-170.

Sárospataki M., Novak J., Molnar V. (2005) Assessing the threatened status of bumble bee species (Hymenoptera: Apidae) in Hungary, central Europe, Biodivers. Conserv. 14, 2437-2446.

Schoonhoven L.M., Jermy T., van Loon J.J.A. (1998) Insect-Plant Biology: From Physiology to Evolution, Chapman \& Hall, London.

Settele J., Hammen V., Hulme P., Karlson U., Klotz S., Kotarac M., Kunin W., Marion G., O’Connor M., Petanidou T., Peterson K., Potts S., Pritchard H., Pysek P., Rounsevell M., Spangenberg J., SteffanDewenter I., Sykes M., Vighi M., Zobel M., Kühn I. (2005) ALARM: Assessing large-scale environmental risks for biodiversity with tested methods, Gaia 14, 69-72.

Settele J., Biesmeijer J.C., Grabaum R., Hammen V.C., Hulme P.E., Karlson U., Klotz S., Kotarac M., Kunin W.E., Marion G., O’Connor M., Petanidou T., Peterson K., Potts S.G., Pysek P., Rattei S., Rounsevell M. (2007) Environmental risk assessment for biodiversity and ecosystems: results and perspectives of the large scale interand transdisciplinary research of the ALARM Project, in: Emerging Issues for Biodiversity Conservation in a Changing Climate, pp. 5053, Montreal, Secretariat of the Convention on Biological Diversity. Abstracts of poster presentations at the 12th meeting of the subsidiary body on scientific, technical and technological advice of the Convention on Biological Diversity. ISBN: 929225-073-6.

Shepherd M.D., Vaughan D.M., Black S.H., Eds. (2005) Red List of Pollinator Insects of North
America. CD-ROM Version 1 (May 2005), The Xerces Society for Invertebrate Conservation, Portland, Oregon.

Steffan-Dewenter I., Tscharntke T. (1999) Effects of habitat isolation on pollinator communities and seed set, Oecologia, 121, 432-440.

Stout J.C., Morales C.L. (2009) Ecological impacts of invasive alien species on bees, Apidologie 40, 388-409.

Tang J., Wice J., Thomas V.G., Kevan P.G. (2005) Assessment of the capacity of Canadian Federal and Provincial legislation to conserve native and managed pollinators, A Report Compiled by The International Network of Expertise for Sustainable Pollination at the request of The North American Pollinator Protection Campaign.

The Xerces Society for Invertebrate Conservation (2008) Invertebrate conservation fact sheet 2008 Farm Bill benefits to crop pollinators, [online] http://www.xerces.org/wp-content/uploads/2008/ 11/2008_farm_bill_fact_sheet_xerces_society. pdf (accessed on: 13 February 2009).

Thorp R.W. (2000) The collection of pollen by bees, Plant Syst. Evol. 222, 211-233.

Thorp R.W. (2005) Species Profile: Bombus franklini, in: Shepherd M.D., Vaughan D.M., Black S.H. (Eds.), Red List of Pollinator Insects of North America, CD-ROM Version 1 (May 2005), Portland, OR: The Xerces Society for Invertebrate Conservation.

Waser N.M., Ollerton J. (Eds.) (2006) PlantPollinator Interactions: From Specialization to Generalization, University of Chicago Press, Chicago.

Watanabe M.E. (1994) Pollination worries rise as honey bees decline, Science 265, 1170.

Williams P.H. (1998) An annotated checklist of bumble bees with an analysis of patterns of description (Hymenoptera: Apidae, Bombini), Bull. Nat. Hist. Mus. Lond. (Entomol.) 67, 79-152.

Williams P.H., Osborne J.L. (2009) Bumblebee vulnerability and conservation world-wide, Apidologie 40, 367-387.

Williams I.H. (2003) The Convention on Biological Diversity adopts the International Pollinator Initiative, Bee World 84, 27-81. 